\title{
Synthesis and biological activity of acetylacetone thiosemicarbazone and their metallic complexes
}

\author{
*Sandeep Kumar' ${ }^{1}$ Nitin Kumar ${ }^{2}$ \\ ${ }^{1}$ Department of Pharmacy, Vivek College of Technical Education, Bijnor, UP, India \\ ${ }^{2}$ School of Pharmacy, Galgotias University, Noida, UP, India
}

\begin{abstract}
In present work, Ligand acetylacetone thiosemicarbazone and their 11 complexes of the type $\mathrm{ML}_{2} \mathrm{X}_{2}, \mathrm{ML}_{2} \mathrm{X}^{\prime}$, where $\mathrm{M}$ $=\mathrm{Cu}(\mathrm{II}), \mathrm{Cd}(\mathrm{II}), \mathrm{Co}(\mathrm{II}), \mathrm{Zn}(\mathrm{II}), \mathrm{Hg}(\mathrm{II}) ; \mathrm{L}=$ acetylacetone thiosemicarbazone; $\mathrm{X}=\mathrm{Cl}, \mathrm{NO}_{3}$ or $\mathrm{CH}_{3} \mathrm{COO} \mathrm{X}^{\prime}=\mathrm{SO}_{4}$ have been synthesized and characterized with the help of molar conductance, magnetic susceptibility measurements, infrared and ultra-violet spectroscopy. The spectral data revealed that the thiosemicarbazone act as bidentate ligand, making use of thionic sulphur and the azomethine nitrogen atom for co-ordination to the central metal atom. All the compounds have been screened for their antibacterial activity against Gram positive bacteria Staphylococcus aureus, Staphylococcus epidermidis and Gram negative bacteria Escherichia coli and Pseudomonas aeruginosa. Some of complexes exhibited appreciable activity.
\end{abstract}

Key Words: Thiosemicarbazone, thiosemicarbazone complexes, metallic complexes, characterization, antibacterial activity and spectral studies.

\section{INTRODUCTION}

Thiosemicarbazones are of considerable interest because of their chemistry and potentially beneficial biological activity, such as antibacterial, antifungal, antiviral, antiamoebic, antimalarial and antitumor activity (Klayman et al., 1979; Scovill et al., 1984; Klayman et al., 1984; Liberta et al., 1992; West et at., 1993; Liu et al., 1995; Sharma et al., 2005; Rebolleo et al., 2005). The biological activities of thiosemicarbazones are considered to be due to their ability to form chelates with metals. Biological activities of metal complexes differ from those of either ligands or the metal ions, and increase and/or decreased biological activities are reported for several transition metal complexes. Thiosemicarbazone are versatile compounds; two structural isomers (E-, Z form) are possible and they can co-ordinate to the metal either as a neutral ligand or as a deprotonated ligand through the NS atoms (West et al., 1996; Kasuga et al., 2003).

\footnotetext{
*Corresponding Author:

Sandeep Kumar

Assistant Professor, Department of Pharmacy

Vivek College of Technical Education

Bijnor, UP, India

E-mail: sandeep.mpharm@gmail.com

Contact No.: +919997789752
}

In this work, ligands acetylacetone thiosemicarbazone and their eleven metallic complexes were prepared and characterized by molar conductance, magnetic susceptibility measurements, ultra-violet and infra-red spectroscopy. Their antibacterial activities were evaluated by measuring the zone of inhibition using disc diffusion method against Gram positive bacteria Staphylococcus aureus, Staphylococcus epidermidis and Gram negative bacteria Escherichia coli and Pseudomonas aureginosa.

\section{EXPERIMENTAL}

\section{Material and measurements}

All the chemicals and solvents of SigmaAldrich/CDH/Rankem/Merck were AR grade and used without any further purification. All the reaction were monitored by TLC using methanol:chloroform (9:1) as solvent system. TLC plates were prepared by spreading method and are dried in air and activated by heating in hot air oven at $110^{\circ} \mathrm{C}$ for 20 minutes. Iodine chamber was used for visualization of TLC spots. Melting point of all synthesized compounds was determined in open glass capillaries. Magnetic susceptibility measure- 


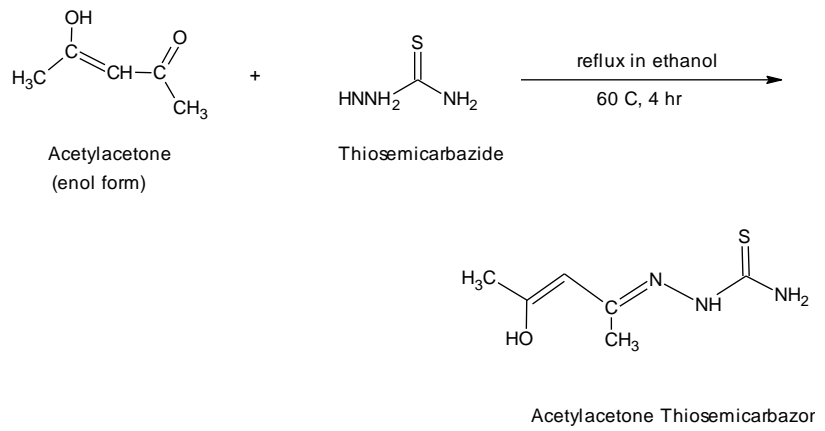

Figure 1: Synthesis of ligand(L); Acetylacetone Thiosemicarbazone $\left(\mathrm{C}_{6} \mathrm{H}_{12} \mathrm{~N}_{3} \mathrm{OS}\right)$.

ments were carried out in the polycrystalline state on a Vibrating Sample magnetometer. IR spectra were recorded by making $\mathrm{KBr}$ pellets on Jasco fourier transform IR spectrophotometer (FT/IR4100). UV spectra were recorded by making methanol solution on Systronic pc based double beam spectrophotometer 2202. All the synthesized compounds were screened for their antibacterial activity using agar diffusion method.

Thiosemicarbazide $(0.01 \mathrm{~mol}, 0.91 \mathrm{~g})$ was dissolved in ethanol (approx. 60ml) by refluxing at $50^{\circ} \mathrm{C}$ in 250 $\mathrm{ml} \mathrm{Rbf.} \mathrm{In} \mathrm{the} \mathrm{refluxing} \mathrm{solution,} \mathrm{the} \mathrm{acetylacetone}$ $(0.01 \mathrm{~mol}, 1.02 \mathrm{ml})$ solution in ethanol (approx. $30 \mathrm{ml})$ was added. The reaction mixture was refluxed for four hours at $60^{\circ} \mathrm{C}$. The volume of reaction mixture was reduced and then cooled on ice water. The crystals of acetylacetone thiosemicarbazone were precipitate out. The crystals were recrystallized by ethanol. Yield: $1.62 \mathrm{~g}(90 \%)$; m.p.: $119^{\circ} \mathrm{C}$; TLC: Rf: $0.94\left(\mathrm{CHCl}_{3}: \mathrm{CH}_{3} \mathrm{OH}, 9: 1, \mathrm{v} / \mathrm{v}\right)$.

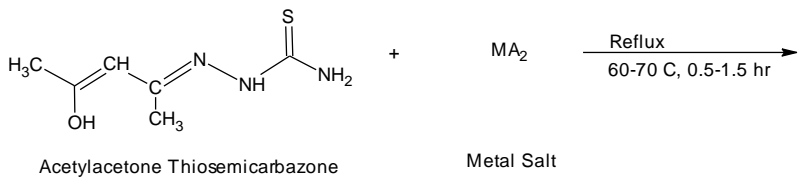<smiles>CC(O)=CC(C)=NN(C)[Y]1(C)SC(N)=[SH][N+]1(C)N(NC(N)=CC(C)O)C(C)=CC(C)O</smiles>

Metal Complex of Acetylacetone Thiosemicarbazone

Figure 2: Synthesis of metal complexes of Acetylacetone Thiosemicarbazone.

Ethanol solution of metal salts was refluxed with ethanol solution of acetylacetone thiosemicarbazone in 1:2 ratio for $0.5-1.0 \mathrm{hr}$. Volume of the resulting clear solution was reduced to $10 \mathrm{ml}$ by a rotary vacuum evaporator and the solution was left overnight. The resulting crystalline compounds were filtered under suction, washed with ethanol and ether, and dried in vacuum.

\section{RESULTS AND DISCUSSION}

\section{Physical Properties}

Complexes reported in the present investigation have the general composition $\mathrm{ML}_{2} \mathrm{X}_{2}$ and $\mathrm{ML}_{2} \mathrm{X}^{\prime}$, where $\mathrm{M}=\mathrm{Cu}(\mathrm{II}), \mathrm{Cd}(\mathrm{II}), \mathrm{Co}(\mathrm{II}), \mathrm{Zn}(\mathrm{II}), \mathrm{Hg}(\mathrm{II}) ; \mathrm{L}=$ acetylacetone thiosemicarbazone; $\mathrm{X}=\mathrm{Cl}$ or $\mathrm{NO}_{3}$ or $\mathrm{CH}_{3} \mathrm{COO} ; X^{\prime}=\mathrm{SO}_{4}$. These are crystalline compounds. The complexes of copper(II) are green,

Table 1: Analytical data of compounds.

\begin{tabular}{|c|c|c|c|c|c|c|}
\hline Comp. no. & Comp. & $\begin{array}{c}\% \\
\text { Yield }\end{array}$ & m.p. & $\begin{array}{l}\text { Conductance } \\
\Omega^{-} \mathrm{cm}^{2} \mathrm{~mol}^{-1}\end{array}$ & $\begin{array}{l}\text { Meff } \\
\text { B.M. }\end{array}$ & Soluble in \\
\hline Comp. 1 & $\mathrm{~L}$ & 90 & 119 & - & - & Ethanol, Chloro- form \\
\hline Comp. 2 & {$\left[\mathrm{CuL}_{2} \mathrm{Cl}_{2}\right]$} & 42 & 209 & 8.8 & 1.76 & DMSO, DMF \\
\hline Comp. 3 & {$\left[\mathrm{CuL} 2\left(\mathrm{NO}_{3}\right)_{2}\right]$} & 32 & 250 & 10.6 & 1.80 & DMSO, DMF \\
\hline Comp. 4 & {$\left[\mathrm{CuL}_{2} \mathrm{SO}_{4}\right]$} & 37 & 205 & 9.6 & 1.91 & DMSO, DMF \\
\hline Comp. 5 & {$\left[\mathrm{CdL}_{2} \mathrm{SO}_{4}\right]$} & 73 & 220 & 9.2 & 3.6 & DMSO, DMF \\
\hline Comp. 6 & {$\left[\mathrm{CoL}_{2} \mathrm{Cl}_{2}\right]$} & 28 & 238 & 10.5 & 4.9 & DMSO, DMF \\
\hline Comp. 7 & {$\left[\mathrm{CoL}_{2}\left(\mathrm{No}_{3}\right)_{2}\right]$} & 30 & 203 & 9.8 & 4.8 & DMSO, DMF \\
\hline Comp. 8 & {$\left[\mathrm{ZnL}_{2} \mathrm{Cl}_{2}\right]$} & 37 & 218 & 11.2 & - & DMSO, DMF \\
\hline Comp. 9 & {$\left[\mathrm{ZnL}_{2}\left(\mathrm{No}_{3}\right)_{2}\right]$} & 29 & 242 & 10.4 & - & DMSO, DMF \\
\hline Comp. 10 & {$\left[\mathrm{ZnL}_{2} \mathrm{SO}_{4}\right]$} & 60 & 230 & 9.3 & - & DMSO, DMF \\
\hline Comp. 11 & {$\left[\mathrm{ZnL}_{2}\left(\mathrm{CH}_{3} \mathrm{COO}\right)_{2}\right]$} & 24 & 210 & 8.9 & - & DMSO, DMF \\
\hline Comp. 12 & {$\left[\mathrm{HgL}_{2} \mathrm{SO}_{4}\right]$} & 28 & 243 & 11.2 & 2.3 & DMSO, DMF \\
\hline
\end{tabular}


Table 2: Infra-red $\left(\mathrm{cm}^{-1}\right)$ and ultra-violet $\left(\lambda_{\max }\right.$ in $\left.\mathrm{nm}\right)$ spectrum data of compounds.

\begin{tabular}{cccc}
\hline Comp. & $\boldsymbol{v}(\mathbf{C}=\mathbf{N})$ & $\boldsymbol{v}(\mathbf{C}=\mathbf{S})$ & $\boldsymbol{\lambda}_{\max }$ \\
\hline Comp.1 & 1620 & 800 & 272 \\
Comp.2 & 1593 & 751 & 245 \\
Comp.3 & 1595 & 744 & 248 \\
Comp.4 & 1572 & 699 & 232 \\
Comp.5 & 1575 & 739 & 259 \\
Comp.6 & 1595 & 719 & 260 \\
Comp.7 & 1598 & 720 & 238 \\
Comp.8 & 1597 & 749 & 268 \\
Comp.9 & 1595 & 743 & 265 \\
Comp.10 & 1586 & 740 & 269 \\
Comp.11 & 1578 & 746 & 286 \\
Comp.24 & 1553 & 738 & 241 \\
\hline
\end{tabular}

cadmium(II) are cream, cobalt(II) are dark orange, zinc(II) are white, and mercury(II) are black. All the complexes have low molar conductance values in acetone medium indicating their non-electrolytic nature. All the complexes have $\mu$ eff values in the range of 1.82 to 4.9 B.M indicating presumably a spin-free octahedral or distorted octahedral configuration of these compounds (Table 1).

\section{Infra-Red Spectra}

IR spectra of compounds provide evidence regarding the bonding sites in the complexes. Acetylacetone thiosemicarbazone shows a broad band around 3450 $\mathrm{cm}-1$ indicating that there is free $\mathrm{OH}$ group involved in some type of hydrogen bonding and the ligand is a monothiosemicarbazone. In complexes $v(\mathrm{OH})$ is observed around $3450 \mathrm{~cm}-1$, indicating that the $\mathrm{OH}$ group has not taken part in coordination. $v(C=S)$ in the ligand is observed at $800 \mathrm{~cm}-1$ but in the complexes, it is found in the $720-750 \mathrm{~cm}-1$ region suggesting the bonding through sulphur of the thiocarbonyl group. $v(\mathrm{C}=\mathrm{N})$ with some amount of contribution of $\delta(\mathrm{NH} 2)$ is found at $1620 \mathrm{~cm}-1$ and a lowering in frequency of this band on complexes formation supports the coordination through the terminal hydrazine nitrogen (Table 2).

Table 3: Antibacterial activity of compounds (comp. 1 to 12) and standard.

\begin{tabular}{|c|c|c|c|c|c|}
\hline \multirow{3}{*}{ Comp. } & \multirow{3}{*}{$\begin{array}{l}\text { Conc. of comp. } \\
\text { per disc }\end{array}$} & \multicolumn{2}{|c|}{ Gram Positive Bacteria } & \multicolumn{2}{|c|}{ Gram Negative Bacteria } \\
\hline & & S. aureus & S. epidermidis & E. coli & P. auriginosa \\
\hline & & \multicolumn{4}{|c|}{ Zone of inhibition in mm (mean of three replicates) } \\
\hline \multirow{2}{*}{ Comp. 1} & $30 \mu \mathrm{g}$ & - & - & - & - \\
\hline & $200 \mu \mathrm{g}$ & 4 & 3 & 3 & - \\
\hline \multirow{2}{*}{ Comp. 2} & $30 \mu \mathrm{g}$ & 6 & 8 & 9 & 5 \\
\hline & $200 \mu \mathrm{g}$ & 14 & 12 & 13 & 9 \\
\hline \multirow{2}{*}{ Comp. 3} & $30 \mu \mathrm{g}$ & 6 & 9 & 5 & 8 \\
\hline & $200 \mu \mathrm{g}$ & 13 & 11 & 10 & 15 \\
\hline \multirow{2}{*}{ Comp. 4} & $30 \mu \mathrm{g}$ & 3 & 3 & 4 & 4 \\
\hline & $200 \mu \mathrm{g}$ & 10 & 9 & 9 & 10 \\
\hline \multirow{2}{*}{ Comp. 5} & $30 \mu \mathrm{g}$ & 6 & 6 & 5 & 6 \\
\hline & $200 \mu \mathrm{g}$ & 13 & 11 & 13 & 14 \\
\hline \multirow{2}{*}{ Comp. 6} & $30 \mu \mathrm{g}$ & 3 & - & - & 2 \\
\hline & $200 \mu \mathrm{g}$ & 10 & 7 & 6 & 6 \\
\hline \multirow{2}{*}{ Comp. 7} & $30 \mu \mathrm{g}$ & 3 & - & - & 3 \\
\hline & $200 \mu \mathrm{g}$ & 9 & 7 & 7 & 8 \\
\hline \multirow{2}{*}{ Comp. 8} & $30 \mu \mathrm{g}$ & 6 & 5 & 7 & 7 \\
\hline & $200 \mu \mathrm{g}$ & 12 & 10 & 16 & 13 \\
\hline \multirow{2}{*}{ Comp. 9} & $30 \mu \mathrm{g}$ & 5 & 4 & 5 & 4 \\
\hline & $200 \mu \mathrm{g}$ & 10 & 9 & 8 & 10 \\
\hline \multirow{2}{*}{ Comp. 10} & $30 \mu \mathrm{g}$ & 4 & 3 & 2 & 3 \\
\hline & $200 \mu \mathrm{g}$ & 8 & 9 & 7 & 6 \\
\hline \multirow{2}{*}{ Comp. 11} & $30 \mu \mathrm{g}$ & 5 & 4 & 8 & 4 \\
\hline & $200 \mu \mathrm{g}$ & 6 & 7 & 11 & 10 \\
\hline \multirow{2}{*}{ Comp. 12} & $30 \mu \mathrm{g}$ & 10 & 11 & 8 & 8 \\
\hline & $200 \mu \mathrm{g}$ & 19 & 16 & 14 & 16 \\
\hline Amikacin & $30 \mu \mathrm{g}$ & 20 & 21 & 21 & 24 \\
\hline
\end{tabular}




\section{Ultra-Violet spectra}

UV spectra of ligand and complexes were recorded in methanol. In UV spectra ligand shows $\lambda_{\max }$ at 272 $\mathrm{nm}$ with a shoulder band. It indicates that in methanol solution the ligand exist in thiol form. After complexation, $\lambda_{\max }$ shifted to lower frequency/higher frequency depending upon the centre metal atom. The increase in intensity is attributed to extended conjugation in the ligand moiety after complexation (Table 2).

\section{Biological activity}

The synthesized compounds were tested for their antibacterial activity by measuring the inhibition area on agar plates (diffusimetric method) with Gram positive bacteria Staphylococcus aureus MTCC 737, Staphylococcus epidermidis MTCC 3615 and Gram negative bacteria Escherichia coli MTCC 1687, and Pseudomonas aureginosa MTCC 1687. The results of antibacterial activity of complexes together with the result of free butanone thiosemicarbazone as comparison are listed in table 3, as estimated by zone of inhibition (mm).

The results show that free thiosemicarbazone (comp. 1) does not have effective antimicrobial activity against selected test organisms, while complexes (comp. 2 to 12) have effective antimicrobial activity. The comp. 12 showes good activity against the entire test organism. The comp. 2, 3, 5 and 8 posses moderate activity while remaining compounds show poor activity against test organisms.

\section{CONCLUSION}

The ligand, acetylacetone thiosemicarbazone and their metallic complexes were synthesized and characterized by the infra-red and ultra-violet spectroscopic method. It is examined that in these comoplexes the ligand has NS donor bidentate nature. The biological behavior revealed that ligand shows a weak activity against the test bacterial strains. The chelation induced significant changes in the biological activity of the ligand. Complexes (comp. 12) show good activity against the selected test organisms.

\section{REFERENCES}

Chandra S. and Gupta L.K., (2005) Spectroscopic and biological studies on newly synthesized nickel(II) complexes of semicarbazone and thiosemicarbazones, Spectrochimica Acta Part A.; 62;1089. [DOI] PMid:16144772

Demertzi D.K., Miller J.R., Kourkoumelis N., Hadzikaaou S.K. and Demertzis M.A. (1999) Palladium(II) and Platinum(II) complexes of pyridine-2-carbaldehyde thiosemicarbazone with potential biological activity. Synthesis, structure and spectral Properties. Extended network via hydrogen bond linkages of [Pd (PyTsc)Cl]', Polyhedron;18;1005. [DOI]

Ferrari B.M., Fava G.G. Leporti E., Pelosi G., Rossi R., Tarasconi P., Albertini R., Bonati A., Lunghi P. and Pinelli S., (1998) Synthesis, characterization and biological activity of three copper (II) complexes with a modified nitrogenous base: 5formyl uracil thiosemicarbazone, J. Inorganic Biochem.; 70;145. [DOI]

Ferrari M.B., Capacchi S., Reffo G., Aelosi G., Tarasconi P., Albertini R., Pinellis S., Lunghi p., (2000) Synthesis, structural characterization and biological activity of $\mathrm{P}$ fluorobenzaldehyde thiosemicarbazones and of a nickel complexes', J. of Inorg. Biochem.; 81; 89. [DOI]

Kasuga N.C., Sekino K., Ishikawa M., Honda A., Yokoyama M., Nakano S., Shimada N., Koumo C. and Nomiya K., (2003) Synthesis, structural characterization and antimicrobial activities of 12 zinc(II) complexes with four thiosemicarbazone and two semicarbazone ligands, J. Inorg. Biochem.; 96; 298. [DOI]

Klayman D.L., Bartosevich J.F., Griffine T.S., Mason C.J. and Scovill J.P. (1979) '2-Acetylpyridine Thiosemicarbazones; 2-A New Class of Potential Antimalarial Agents', J. Med. Chem.; 22; 1367-1373. [DOI]

Klayman D.L., Scovill J.P., Bruce J. and Bartosevich J., (1984) '2Acetylpyridine Thiosemicarbazones; 9-Derivative of 2-Acetyl isoquinoline as potential antimalarial agents' J. Med. Chem.; 27; 84. [DOI] PMid:6361257

Liberta A. E. and West D.X., (1992) 'Antifungal and Antitumour Activity of Hetrocyclic Thiosemicarbazones and their Metal Complexes', BioMetal; 5; 121. [DOI]

Lobana T.S., Rekha, Butcher R.J., Castineiras A., Bermejo E. and Bharatam P.V., (2006) 'Bonding trends of thiosemicarbazone in mono nuclear and di nuclear copper complexes : synthesis, structures and theoretical aspects' Inorg. Chem.; 45; 1535. [DOI] PMid:16471964

Sharma S., Athar F., Maurya M.R., Azam A., (2005) 'copper(II) complexes with substituted thiosemicarbazone of thiophene 2-carboxaldehyde : synthesis, characterization and antiamoebic activity against E. histolytica' European J. Med. Chem.; 40;1414. [DOI] PMid:16129515

West D.X., Brain G.A., Jasinski J.P., Li Y., Pozdniakiv R.Y., Martinez J. V., Toscano R.A. and Ortega S. H., (1996) 'Structural studies of three isomeric forms of hetrocyclic N(4)substituted thiosemicarbazone and their two nickel complexes', Polyhedron; 15; 665. [DOI] 